\title{
Die NHKA op reis na inklusiwiteit I: Die anatomie van 'n gefragmenteerde/eskatologiese ekklesiologie
}

\author{
Authors: \\ Johan Buitendag ${ }^{1}$ \\ Tanya van Wyk $^{1}$ \\ Affiliation: \\ ${ }^{1}$ Department of Dogmatics \\ and Christian Ethics, \\ University of Pretoria, \\ South Africa \\ Correspondence to: \\ Tanya van Wyk \\ Email: \\ tanya.vanwyk@up.ac.za \\ Postal address: \\ University of Pretoria, Faculty \\ of Theology, Department \\ Dogmatics and Christian \\ Ethics, Lynwood Road, \\ Hatfield, 0083, Pretoria, \\ South Africa \\ Dates: \\ Received: 23 Aug. 2011 \\ Accepted: 30 Aug. 2011 \\ Published: 04 Nov. 2011 \\ How to cite this article: \\ Buitendag, J. \& Van Wyk, T., \\ 2011, 'Die NHKA op reis na \\ inklusiwiteit I: Die anatomie \\ van 'n gefragmenteerde/ \\ eskatologiese ekklesiologie', \\ HTS Teologiese Studies/ \\ Theolocial Studie 67(3), \\ Art. \#1164, 8 pages. http:// \\ dx.doi.org/10.4102/hts. \\ v67i3.1164
}

C 2011. The Authors. Licensee: AOSIS OpenJournals. This work is licensed under the Creative Commons Attribution License.
The NRCA en route to inclusivity I: The anatomy of a fragmented/eschatological ecclesiology This is the first in a two-part series that aims to examine the growing pains the Netherdutch Reformed Church is experiencing in its journey towards Christian inclusivity. This first article examines the fragmentation in the Church's understanding of ecclesiology, which becomes apparent in the debates concerning the meaning and range of inclusivity in ecclesiology. The roots of this fragmentation are examined. It is concluded that the root of the fragmentation is an eschatological understanding of the essence of the church, which is, in turn, due to a fragmented view of humanity. In order for the Church to continue its journey towards inclusivity it should revisit its understanding of humanity and theological anthropology. The second article will focus on the content and implications of a revisited theological anthroplogy.

\section{Inleiding}

Hierdie artikel word aan professor T.F.J. Dreyer opgedra as erkenning van sy op-reis-wees na inklusiwiteit saam met die NHKA - 'n uittreksel uit sy preek as uittredende voorsitter van die Algemene Kerkvergadering aan die 69ste Algemene Kerkvergadering lees: 'Die Bybel sê alle mense is gelyk voor God en dat ons nie teenoor ander mag diskrimineer nie. Watter gewig moet dít dra in ons besluite oor homoseksuele mense en ons apartheidsverlede?' (Dreyer 2011a:4). Tydens sy rede met die opening van die Hervormde Teologiese Kollege in 2011, het hy die volgende opmerking gemaak: 'Jesus verkondig die boodskap dat alle mense by God welkom is' (Dreyer 2011b).

In die Nederduitsch Hervormde Kerk van Afrika (NHKA) ${ }^{1}$ bestaan daar 'n geruime tyd reeds 'n gesprek (oftewel 'n debat) oor die betekenis van die begrip 'inklusiwiteit' in die ekklesiologie.

Die wortels van hierdie diskoers kan waarskynlik byna 30 jaar teruggespoor word na die aanvang van die ekumeniese isolasie van die NHKA met die vergadering van die destydse Wêreldbond van Hervormde Kerke, oftewel die World Alliance of Reformed Churches (WARC) ${ }^{2}$ te Ottawa 1982. Tydens die vergadering is die NHKA deur die WARC gevra om 'n duidelike uitspraak teen apartheid te maak na hierdie vergadering se aanvaarding van 'n status confessionis oor apartheid. Die Kerk het dit egter nie gedoen nie, is gevolglik gesuspendeer en het toe kort daarna uit hierdie liggaam bedank.

Die gesprek oor inklusiwiteit in die ekklesiologie het weer begin momentum kry in die aanloop tot die 68ste Algemene Kerkvergadering (AKV) van die NHKA (vgl. Van Wyk \& Buitendag 2008:1449). Tydens hierdie vergadering moes die lede daarvan ' $n$ besluit neem ten gunste van of teen die verwydering van die term 'volkskerk' uit die prinsipiële dele van kerkorde van die NHKA, ${ }^{3}$ naamlik dié dele waarin die belydenis van die NHKA oor die identiteit en aard van die Hervormde Kerk voorkom. Dat hierdie debat oor die term 'volkskerk' ook 'n debat oor die aard en omvang van inklusiwiteit was, blyk veral uit kommentaar oor die voorgestelde wysigings wat vanuit gemeentes van die Kerk ontvang is. Dit het onder meer ingesluit dat 'voorgestelde wysigings aan die Kerkorde die wese van die NHKA sal raak, want dan sal die kerk oop wees vir almal' (outeur se eie beklemtoning - NHKA 2007:12). Op hierdie vergadering en die daaropvolgende 69ste AKV het die meerderheid van die vergadering ten gunste van die verwydering van die woord volkskerk uit die huidige Kerkorde van die NHKA gestem. In beide gevalle kon die besluit egter nie deurgevoer word nie aangesien die tweederde meerderheid wat kerkordelik nodig is om 'n Ordereël te verander, nie bereik is nie (NHKA 1997:69, 2008:200, 2011a:60).

1.Hierna word onderskeidelik na die NHKA as die Kerk (met 'n hoofletter) of die Hervormde Kerk verwys.

2.In 2010 het die Wêreldbond van Gereformeerde Kerke (World Alliance of Reformed Churches - WARC) met die Gereformeerde Ekumeniese Raad (Reformed Ecumenical Council - REC) saamgesmelt om die Wêreldgemeenskap van Gereformeerde Kerke (World Communion of Reformed Churches - WCRC) te vorm (NHKA 2011a).

3.Die verskil tussen ' $n$ Ordereël en ' $n$ Ordinansie is substansieel. Ordereëls is wesenlike sake en Ordinansies is die praktiese maatreëls vir die uitvoer van die wesensaak. Daar word soveel gewig aan 'n Ordereël verleen dat dit volgens Ordereël 10.1 (iii) slegs deur 'n tweederde meerderheid van stemme gewysig kan word (NHKA 1997:112). ' $n$ Ordereël het dus aansienlik meer gewig as ' $n$ Ordinansie. 
Die gesprek oor inklusiwiteit in die ekklesiologie het in 2010/2011 'n hoogtepunt bereik. Dit is enersyds te wyte aan een spesifieke besluit wat deur die 69ste AKV geneem is en andersyds aan een spesifieke besluit wat nie deur hierdie vergadering geneem is nie.

Die besluit wat wel geneem is, handel oor die NHKA se afwysing van enige teologiese regverdiging van apartheid. Besluit 54 lui:

Die 69ste Algemene Kerkvergadering maak in die lig van die 68ste Algemene Kerkvergadering se besluit dat dit verkeerd was om ' $n$ bepaalde regeringsbeleid (apartheid) goed te praat, onomwonde die uitspraak dat apartheid nie teologies geregverdig kan word nie. Die kerk verwerp sy goedkeuring van apartheid omdat dit:

- in stryd is met die evangelie van Jesus Christus

- gebaseer is op die idee van onderlinge onversoenklikheid

- onreg sanksioneer

- die beeld van God in mense aantas.

(NHKA 2010:343-344)

Hierdie besluit is met 245 teenoor 173 stemme aanvaar. ' $n$ Aantal predikante en ouderlinge het bykans onmiddellik hulle teenstemme gaan aanteken (NHKA 2011a). Kort na die vergadering het hierdie groep predikante, ouderlinge en ander lidmate hulleself begin organiseer en ' $n$ aantal dokumente opgestel om hulle beswaar teen Besluit 54 te verwoord. Hierdie groep het hulleself geleidelik as eers die Dolerendes, ${ }^{4}$ toe die Steedshervormers en later die Beswaardes binne die NHKA bekendgestel (Komitee van Beswaardes 2011c)

In die kontekstualisering van die Beswaarskrif wat deur hierdie groep uitgereik is, word die volgende opmerking aangaande inklusiwiteit gevind:

... daar [word] net een woord raakgesien ... [dat] die śvó $\gamma \gamma \gamma \varepsilon \dot{\lambda} \lambda i_{0}$

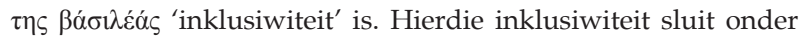
andere in dat enige en alle persone deel van die kerk moet wees, ongeag hulle lewenstyl ... So is dit ook bevestig deur ... aanhoudende pogings om 'n student wat in 'n self-erkende homoseksuele verhouding staan, as student te behou sodat hy ook predikant van die kerk kan word.

(Komitee van Beswaardes 2011b)

Die besluit wat nie geneem is tydens die 69ste AKV nie, is die beskrywingspunt aangaande homoseksualiteit. 'n Uittreksel uit Beskrywingspunt 45 lees:

Die Kerk glo dat alle gedooptes, alle gelowiges, lede van die liggaam van Christus is. Die eenheid van die Kerk as liggaam van Christus is 'n evangeliese eis. Derhalwe is mense wat tot seksuele minderheidsgroepe (of tot watter minderheidsgroepe ook al) behoort, soos alle ander lidmate, welkom in die Christelike geloofsgemeenskap.

(NHKA 2011a:92)

4.Van Wyk (2011c), die voorsitter van die NHKA se Raad vir Regsadvies het die onkritiese gebruik van die begrip Doleansie uitgewys: 'Dit is verbasend dat in die proses van beswaar en wat daarmee saamhang na die Doleansie van 1886 verwys word en die protes teen Beskrywingspunt 54 as doleer beskryf word en daardeur word en die protes teen Beskrywingspunt 54 as doleer beskryf word en daardeur
die weg van separatisme of afskeiding gebaan word, en laasgenoemde was nog nooit eie aan die Hervormde Kerk nie, ook nie aan die Nederlandse Hervormde Kerk nie. Dit was juis die standpunt van Hoedemaker (teenoor Kuyper) wat nie die Kerk nie. Dit was juis die standpunt van Hoedemaker (teenoor Kuyper) wat nie die
pad van separatisme wou gaan nie maar eerder herorganisasie voorgestaan het en pad van separatisme wou gaan nie maar eerder herorganisasie voorgestaan
daarom nie deel gevorm het van Kuyper se doleansie nie' (NHKA 2011c:3).
Die feit dat die meerderheid van die vergadering nie stemgewys positief op die bewoording van hierdie beskrywingspunt, 'dat alle gedooptes, alle gelowiges, deel van die lede van die liggaam van Christus is', gereageer het nie, dui op 'n inherente debat oor watter persone op grond waarvan by die kerk ingesluit word - dus die debat oor inklusiwiteit in ekklesiologie. Dit word ook aangedui deur die stelling uit die kontekstualisering van die beswaarskrif wat bo aangehaal is.

Nog 'n aspek wat deel is van hierdie debat is die verstaan van die reikwydte en inhoud van diversiteit. Dit blyk uit die volgende opmerking wat in die Beswaarskrif ${ }^{5}$ vervat is wat deur die groep uitgereik is: 'Besluit 54 moet nietig verklaar word - hierdie saak duld geen diversiteit nie. Daar kan nie twee uitsluitende waarhede in die kerk geduld word nie' (Komitee van Beswaardes 2011b:4)

Dit blyk ook uit 'n opmerking van 'n lidmaat van die NHKA in Die Hervormer, die amptelike mondstuk van die NHKA:

Die woord wat in ons kerk homself kom staan maak het om vir onderskeie uitgangspunte voorsiening te maak is diversiteit 'n diversiteit wat weinig of geen grense het nie .... [dit] kan nie net aanvaar word dat ' $\mathrm{n}$ woord soos diversiteit in die kerk die towerwoord is om almal te aanvaar en gelukkig te maak nie. Hierdie saak van diversiteit sal in ons Kerk beslis grense moet daarstel.

(NHKA 2011b:2)

Dit is reeds aangetoon dat daar in die NHKA 'n verskeidenheid sake is wat met mekaar verband hou, mekaar beïnloed en bepalend is vir die ekklesiologie van die Hervormde kerk. Dit is die NHKA se verstaan van eenheid en katolisiteit (algemeenheid), die NHKA se historiese identiteit as volkskerk, die NHKA se verstaan van ekumene en die NHKA se amptelike standpunt oor apartheid (Van Wyk \& Buitendag 2008, 2010; vgl. Dreyer 2006, 2011).

Die hipotese van hierdie artikel is dat daar 'n gemeenskaplike faktor (gemene deler) onderliggend aan bogenoemde sake in die NHKA is, wat uitkristaliseer in die NHKA se onderskeid tussen die sigbare en onsigbare kerk. Die artikel poog om die gronde van die NHKA se onderskeid tussen hierdie twee verskynsels of aard van kerkwees vas te stel om sodoende vas te stel wat die Kerk se verstaan van die reikwydte en inhoud van inklusiwiteit beïnvloed en uiteindelik bepaal.

Dit word gedoen om vas te stel of die NHKA inderdaad op reis is na inklusiwiteit in die ekklesiologie en wat die moontlike padversperring kan wees wat die voortsetting van hierdie reis verhinder.

\section{Die ontwikkeling van die sigbare kerk-onsigbare kerk debat}

Die ganse geskiedenis van die NHKA toon dat die Kerk as 'n volkskerk gefunksioneer het (Botha 1973; Dreyer 1995, 1999, 2006, 2011; Koekemoer 1987, 1990; NHKA 1951, 1973 , 5.Die Kontekstualisering van die Beswaarskrif en die Beswaarskrif is twee aparte, maar verwante dokumente (Komitee van Beswaardes 2011a, 2011b). 
1985/6, 1990, 1997; Pont 1989; Van der Westhuizen 1981, 1989). Dit was en is (kyk bo) die uitstaande kenmerk van die Hervormde Kerk se identiteit as kerk (vgl. ook Van Wyk 1999b). Hierdie volkskerklike identiteit, die Kerk se teologiese begronding daarvan (Botha 1973; Dreyer 1995, 2006; Van der Westhuizen 1981; vgl. Oberholzer 2009) en die Kerk se teologiese begronding van aparte ontwikkeling (apartheid) het gelei tot die Kerk se breuk met ekumeniese liggame (vgl. Dreyer 2006, 2011).

Die NHKA se volkskerklike denke het uitdrukking gevind in Artikel III van die 1951 Kerkwet wat self ook 'n eié aanloop en agtergrond gehad het (vgl. Dreyer 1995, 2006). Hierdie artikel het gelees:

Die Kerk, bewus van die gevare wat vermenging van Blank en Nie-Blank vir altwee groepe inhou, wil geen gelykstelling in sy midde toelaat nie, maar beoog die stigting van eie volkskerke onder die verskillende volksgroepe, in die oortuiging dat aldus die bevel van die Here - 'maak dissipels van alle nasies' Matteus 28:19, die beste tot sy reg sal kom en dat die eenheid in Christus deur so 'n werkverdeling nie geskaad sal word nie. Tot die Nederduitsch Hervormde Kerk van Afrika behoort daarom net Blanke persone.

(NHKA 1951)

Vanaf die 1960's ontaard rassekwessies en die NHKA se verstaan van ekumene, soos uitgebeeld in die volkskerkidentiteit en die beklemtoning van Artikel III van die kerkwet egter in 'n krisis wat in 'n sigbare kerk of onsigbare kerkdebat uitgekristaliseer het. Die hoof-verteenwoordigers van hierdie krisis en debat was onder andere aan die eenkant A.S. Geyser, A. van Selms, M.J. Redelingshuys, J.A. van Wyk, J. Stutterheim, B.B. Keet en G.J. Swart, wat elkeen 'n bydrae gelewer het in 'n publikasie getiteld Vertraagde Aksie wat in 1960 verskyn het (Geyser et al. 1960). Aan die ander kant van die debat was onder andere S.P. Engelbrecht, J. Dreyer, H.P. Wolmarans, A.J.G. Oosthuizen, en C.L. van den Berg. Laasgenoemde het 'n publikasie getiteld Onvertraagde Voortgang uitgegee (Van den Berg 1960).

Die handhawing van Artikel III het onder druk verkeer. Tydens die 53ste AKV in 1961 het A.S. Geyser 'n beskrywingspunt ingedien wat vra dat die inhoud van Artikel III aan die 'Heilige Skrif' getoets moet word (NHKA 1961; vgl. Oberholzer 2009:21). Die Hervormde predikante J.A.A.A. Stoop, M.J. Redelinghuys, A. van Selms en C.J. Labuschagne het die beskrywingspunt gesteun. Die vergadering het egter 'n verklaring uitgereik waarin gestel word dat 'uit geslagtelange ervaring met die kleursituasie in Afrika weet die kerk dat die vermenging van blank en nie-blank, veral op die terrein van die kerk, onberekenbare skade doen aan die verkondiging van die Evangelie van Gods Koninkryk' en dat die vergadering die 'goeie reg' en die 'noodsaak' van die handhawing van Artikel III van die Kerkwet bevestig (NHKA 1961). Die debat wat hier gevoer is, het implikasies gehad vir die NHKA se verstaan van die aard van die kerk. Dit blyk uit opmerkings van S.P. Engelbrecht in Die Hervormer van Januarie en Februarie 1961 (Engelbrecht 1961; vgl. Van Wyk 1978:59-60 en Oberholzer 2009:21), waarin hy verklaar het dat Geyser ${ }^{6}$ en Van Selms ${ }^{7}$ deur hulle openbare teenkanting van Artikel III die Reformatoriese onderskeiding tussen die sigbare en die onsigbare kerk ophef. Ook Dreyer (in Van Wyk 1978) lewer kritiek op Van Selms se standpunte deur te verwys na die sigbare-kerk en die onsigbare-kerk:

... verskeidenheid moet nou opgeoffer word aan die god van eenheid ... dat voorstaanders van die eenheidsbeweging tot die gevolgtrekking gekom [het] dat die ou opvatting oor die onsigbare kerk hulle idees en ideale in die weg staan ... dat hierdie broeders die onderskeid van die rasse in die kerk uitgewis wil hê, dat hulle nie meer wil weet van die leer dat die kerk van die Here nie alleen sigbaar, waarneembaar is nie, maar ook onsigbaar.

(Dreyer in Van Wyk 1978:53)

Geyser (1961:9) het gemeen dat die eenheid van die sigbare kerk en die onsigbare kerk dieselfde is omdat die onsigbare kerk vanuit die sigbare kerk gekies word. Engelbrecht, daarenteen, het gemeen dit is wel verskillend (Engelbrecht 1961:9). Van Selms argumenteer vir die opheffing van die onderskeid (in terme van apart-wees) van die sigbare kerk en die onsigbare kerk omdat die gedagte van 'n onsigbare Kerk 'n verleentheidsvlug van teoloë is wat hul gewetens oor die geskeidenheid van die Kerke tot rus wil bring. Maar ... ons mag nie by die geskeidenheid van die Kerke berus nie' (Van Selms in Geyser et al. 1960:43). Dreyer (in Van Wyk 1978) argumenteer ook dat daar nie 'n onderskeid (in terme van apart-wees) tussen die sigbare kerk en onsigbare kerk is nie, maar dat die teenswoordige werklikheid van 'gedeelde kerke' die sigbare aard van die kerk vertoon en dat die onsigbare aard van die kerk wel 'n eenheid in geloof en waarheid vertoon:

die kerk wat in die Apostolicum bely word, is die onsigbare kerk, want as die kerk alleen sigbaar sou wees, sou dit nie meer 'n kwessie van geloof wees nie. Maar die sigbare kerk is gedeeld. Eenheid is daarom geestelik van aard en bestaanbaar by uitwendige kerklike gedeeldheid.

(Dreyer in Van Wyk 1978:53)

Geyser en Van Selms (en diesulkes - kyk bo) argumenteer dus dat daar van die sigbare kerk gepraat móét word omdat enige iets anders neerkom op die ontduiking van die evangeliese opdrag tot kerkeenheid. Dreyer en Engelbrecht (en diesulkes, kyk bo) argumenteer dat daar van die onsigbare kerk gepraat kán word, want aparte volkskerke is 'n praktiese simptoom van die teenswoordige werklikheid. Laasgenoemde word uitgedruk deur Van Niftrik (wat deur Dreyer aangehaal word):

as mens die lidmate en die besture of meerdere vergaderings van die kerk gesien het, dan het 'n mens die werklike kerk nog nie gesien nie. Die werklike kerk sien 'n mens eers dan, as die kerk van Jesus Christus deur die krag van die Heilige Gees ligtend en stralend te voorskyn tree uit haar verborgenheid in kerklike inrigting, tradisie en gewoonte.

(Dreyer 1961:56)

6.Geyser het vir'n geruime tyd toe reeds die Hervormde Kerk se volkskerk-identiteit (en daarmee saam die handhawing van Artikel III) begin kritiseer: " $n$ Boerekerk met sy partypolitieke deelname, sy ekonomiese invloede, sy maatskaplike met sy partypolitieke deelname, sy ekonomiese invloede, sy maatskaplike voortreflikheid, mag nasionale Kerk wees, maar hy het opgehou om Christus-kerk te wees. Hy mag ' $n$ gedugte faktor wees in die staats- en wêreldmag, maar hy sa 1948:5; vgl. Van Eck 1995:832).

7.Van Selms (in Geyser et al. 1960:40) het vrae gevra oor die teenstelling in die Van Selms (in Geyser et al. 1960:40) het vrae gevra oor die teenstelling in die
Hervormde Kerk se belydenis en praktyk: 'Ons bely die gemeenskap van die heiliges, Hervormde Kerk se belydenis en praktyk: 'Ons bely die gemeenskap van die heiliges, maar ons voeg daar stilswyen 
Dus is die kritiek téén en die regverdiging ván aparte volkskerke en aparte ontwikkeling (gegrond op Aritkel III) gegrond op die verstaan van die onderskeid tussen die sigbare en die onsigbare kerk. Geeneen van die verteenwoordigers van die gesprek argumenteer vir die opheffing van die onderskeid tussen die twee verskyningsvorme van die kerk nie. Beide groepe erken dat die sigbare kerk en die onsigbare kerk twee kante van dieselfde muntstuk is. Die een argument plaas die klem op die sigbare kerk, die ander op die onsigbare kerk.

Later sou Hervormde Kerk teoloë, soos B.J. Engelbrecht ${ }^{8}$ (1978a:11-14), F.J. van Zyl (1978:23-26) en A.D. Pont ${ }^{9}$ (1987:43) in hulle argumente oor die volkskerk, die eenheid van die kerk en dus ekumene en apostolaat, ook die sigbare kerk of onsigbare kerk debat aanwend om die klem te plaas op die kerkeenheid wat onsigbaar van aard is.

Uit bogenoemde blyk 'n bepaalde fragmentasie wat die verstaan van die aard van die kerk aanbetref. Die vraag is egter waarop hierdie fragmentasie berus. Dit wil voorkom asof die onderskeie argumente oor die sigbare kerk en die onsigbare kerk en die beklemtoning van één van die twee aspekte gegrond is op die verstaan van eenheid se relasie met eendersheid. Dit sal vervolgens ondersoek word.

\section{Kerk, eendersheid en eenheid}

Uit die opmerkings bo het geblyk dat die sigbare kerk of onsigbare kerk debat telkens na vore getree het in die debat vir of teen die regverdiging van aparte volkskerke. Dit dui op 'n spanning in die verstaan van die eenheid van die kerk. Die beklemtoning van die sigbaarheid van die kerk word ingespan in die beklemtoning van die imperatief van kerkeenheid. Die beklemtoning van die onsigbaarheid van die kerk word ingespan in die beklemtoning van die indikatief van verskeidenheid en dus aparte volkskerke. Uit die talle argumente wat die voorkoms van verskeidenheid as indikatief (gegewe) beklemtoon het (S.P. Engelbrecht 1929; Dreyer 1961; Wolmarans in Van Wyk 1978; vgl. ook B.J. Engelbrecht 1978a:11-14 en Van Zyl 1978:23-26), blyk 'n vrees dat eenheid neerkom op eendersheid - 'n eendersheid van die mense binne die kerk wat in 'n eenheid saamgevoeg sou kon word of nie in 'n eenheid saamgevoeg kan word nie.

Reeds in 1929 betoog S.P. Engelbrecht vir die verskeidenheid van verskillende volke: 'elke volk het sy eie geestesgeaardheid en aanleg, wat 'n groot invloed uitoefen op die wyse waarop die volksiel geestelike dinge beleef' (Engelbrecht in Van Wyk 1978:3). In 1939 wys Dreyer op die gevaar van 'n sogenaamde gelykstellingspolitiek in die kerk en in die staat en verwys na

8.Engelbrecht wys terug na die Reformatoriese onderskeiding tussen die sigbare kerk en onsigbare kerk wat berus op Luther se reaksie teen die Rooms-Katolieke Kerk, wat die eenheid en wese van die kerk afhanklik gemaak het daarvan dat die kerk en eenheid altyd uiterlik sigbaar moet wees. Hierdie kerk en eenheid is aan ' $n$ bepaalde plek en persone gebind, naamlik Rome en die pous en hierteen het Luther kapsie gemaak aangesien die Kerk deur die kerkhervormers beskou is as 'onsigbaar en gemaak, aangesien die Kerk deur die kerkhervormers beskou is as 'onsigbaar en geestelik, deur geloof alleen waarneembaar. Engelbrecht verwys ook na Calvyn ter stawing van argumente oor die sigbare kerk of onsigbare kerk. Engelbrecth verklaar dat Calvyn nooit die sigbare kerk en die onsigbare kerk in waterdigte
kompartemente plaas nie (Engelbrecht in NHKA 1978a:11).

9.Ook Pont meen: die 'twee kerke wat so onderskei word, word nêrens deur Calvyn onderskei nie' (Pont 1987:43) die Voortrekkers wat juis die binneland ingetrek het omdat dit hulle strewe was om geen vermenging tussen Blank en Nie-Blank toe te laat nie: 'elkeen, Blank, sowel as gekleurd, moet langs sy eie lyne ontwikkel, sy eie kultuur opbou en op sy eie geestesgoedere voortbou' (Dreyer in Van Wyk 1978:5). Oosthuizen meen ook dat daar 'n verskeidenheid van volke is en dat die 'Nie-Blankes tot mondingwording moet kom en volwaardige volkstatus bereik. Hoe om dit te doen en nog 'n Blanke beskawing te behou, is die probleem' (Oosthuizen in Van Wyk 1978:9). Wolmarans het gemeen dat die beginsel van geen gelykstelling gehandhaaf moes word want dit was noodsaaklik vir die handhawing van die 'Blanke rasse, van die Westerse beskawing en van die Christelike godsdiens' (Wolmarans in Van Wyk 1978:26). In 1960 skryf Oosthuizen dat die beleid van aparte ontwikkeling, aparte volkskerke en die beginsel van 'geen gelykstelling' waarop Artikel III gegrond is, nie vir die kerk om politieke oorwegings gegaan het nie, maar dat die kerk:

instinktief aangevoel het dat 'n deurmekaarboerdery tot die bitterste wrywing, geknoei en uitoorlêery sou lei ... daarom staan Artikel III in ons kerkwet en moet hy daar bly staan ... 'n deurmekaarboerdery of veelrassige kerk is staat [is] nie aanvaarbaar nie.

(Oosthuizen in Van Wyk 1978:32)

Storm (1992:927) wys daarop dat die Afrikaner teenoor sy medemens 'n selfstandige koning is en dat hierdie selfstandigheid aanleiding gegee het tot die Afrikaner se oortuiging dat daar geen gelykstelling en saam-bestaan van mense van verskillende rasse en taalgroepe kan wees nie. Eie waardes, tradisies en godsdiens kon net in ' $n$ aparte kerkwees en volksbestaan verseker word (Storm 1992:929).

Dit is duidelik dat die kritiek teen gelykstelling, vermenging en integrasie gegrond is op ' $n$ betoog dat eenheid in die kerk en staat nie moontlik is nie omdat die verskille tussen die volke of rassegroepe te groot is. Wat meer is, daar blyk 'n vrees te wees dat ander volke soos die Blanke volk sal word, maar omdat ander volke prinsipieel nie soos die Blanke volk is nie, sal hulle nooit soos die Blanke kan word nie. Slegs 'eendersoortiges' hoort in een groep byeengebring te word.

Dieselfde tipe argumente is ingespan in debatte oor die eenheid en die moontlikheid en wenslikheid van sigbare organisatoriese kerkeenheid.

Van Zyl (1978:23-26) het gemeen dat kerkvereniging te na is aan kerklike sinkretisme en Engelbrecht (1978a:14) dat die gesprek oor die eenheid van die kerk nooit die sigbare vereniging van kerke as uitgangspunt kan hê nie. In 'n dokument wat deur Engelbrecht in 1970 opgestel is en waarin die verskille en ooreenkomste tussen die sogenaamde drie susterskerke, die NHKA, die Nederduitse Gereformeerde Kerk (NGK) en die Gereformeerde Kerke van Suid-Afrika (GKSA) uiteengesit word, is hierdie tendens duidelik. Dit word gestel dat die verskil tussen die NHKA en die GKSA op die twee kerke se verstaan van 'kerklike eenheid' berus. Volgens die GKSA moet die onsigbare kerk wat een is in waarheid, sigbaar tot uitdrukking kom in die eenheid van die kerkverband, terwyl daar geen nasionale grense vir die 
kerk mag wees nie. Die NGK het geoordeel dat die verdeling tussen die genoemde drie Afrikaanssprekende kerke ' $n$ sondige verskeurdheid is omdat daar nie 'n natuurlike verskeidenheid onder die Afrikaners as volk ten opsigte van taal voorkom nie.

Hierteenoor het die NHKA geoordeel dat eenheid in waarheid nie tot een denominasie hoef te lei nie (Historiese Agtergrond van die TKK in NHKA 1991:74). Engelbrecht (1978:288) argumenteer verder dat die verskeidenheid nie as sondige verskeurdheid beskou moet word nie, dat dit slegs sondige verskeurdheid sou wees as 'n groep binne 'n bepaalde kerkgenootskap van daardie bepaalde kerkgenootskap afskei. Wat die ekumene met die genoemde Afrikaanssprekende kerke aanbetref, wil dit voorkom asof die abnormale (verskeurdheid) deur die NHKA as die normale (verskeidenheid) voorgehou word. Verskillende kerke het elkeen verskillende aksente (lees: nie eenders nie) en die sigbare werklikheid van geografie en instituut noodsaak ook hierdie verskeidenheid. Daarom sal organisatoriese kerkeenheid nie wenslik wees nie, want vir almal om in een instituut saamgevoeg te word, beteken dat almal eenders is (volgens bogenoemde argument) en dit is nóg moontlik, nóg wenslik.

Die spanning in die verstaan van die relasie tussen eenheid en eendersheid blyk ook uit 'n publikasie van A.B. du Preez (1959), getiteld Eiesoortige ontwikkeling tot volksdiens: Die hoop van Suid-Afrika waarin hy betoog dat, indien Paulus (Gal 3:28; Kol 3:11) bedoel het dat daar in die kerk geen onderskeid getref moet word tussen Jode en Grieke, slawe en vrymanne, mans en vroue nie en dat hulle 'n sigbare eenheid moet vorm, dan beteken dit dat mans en vroue eenders moet wees en dit is onmoontlik. Dus meen Du Preez (1959:67) dat Paulus nie 'n sigbare eenheid van die kerk vereis nie. Geyser meen dat Paulus wel die eenheid van die kerk bepleit, maar nie die eendersheid van die lede van die kerk nie (Geyser et al. 1960:9-10).

Uit hierdie betoë blyk dat die belydenis van onsigbare kerkeenheid beskou word as die oorbrugging van die spanning tussen die empiriese veelheid van kerke en die belydenis van die eenheid van die kerk. Sigbare kerkeenheid word gekritiseer en ontmoedig dat dit noodwendig beteken dat eendersheid die voorvereiste vir die eenheid is - en die Hervormde Kerk se geskiedenis het aangetoon dat dit (die Kerk) ten alle koste die Kerk se eie identiteit wil behou en dat die beste manier om dit te doen, deur afsondering is. In die sigbare kerk of onsigbare kerk word eenheid van eendersheid afhanklik gemaak. Dit veroorsaak 'n gefragmenteerde ekklesiologie.

\section{Kerk, koninkryk en eskatologie}

In die Hervormde Kerk is daar 'n spanning tussen kerkeenheid en die verskeidenheid van menswees, wat nie deur gedwonge sigbare organisatoriese kerkeenheid of onsigbare kerkeenheid ten opsigte van geloof en waarheid tussen aparte volkskerke opgelos word nie.
Die resente geskiedenis van die NHKA vertoon die opkoms van 'n kompromis tussen hierdie twee uiterstes, naamlik die konsep van versoenende verskeidenheid (NHKA 2008:9). Dit behels 'n dialektiese spanning tussen eenheid en verskeidenheid, maar ook tussen inklusiwiteit en eksklusiwiteit. Die teenwoordige deelwoord (versoenende), dui daarop dat dit 'n voortgaande handeling is, en nooit afgehandel sal wees nie. Die kerk is eksklusief omdat dit bestaan uit mense wat geloof bely in Jesus Christus (NHKA 2008:2-3). Mense wat nie hierdie belydenis handhaaf nie, bevind hulle buite die gemeenskap van gelowiges, hoewel gelowiges aan hulle die evangelie verkondig en God se liefde betoon. Die kerk is egter ook inklusief, omdat daar benewens die verskil in amp en bediening, ${ }^{10}$ verskille ten opsigte van die aard van mense bestaan.

Die probleem is egter dat die Hervormde Kerk die konsep van versoenende verskeidenheid tot op hede nie in 'n gunstige lig beskou het nie. Gedurende die 68ste AKV het die beskrywingspunt oor versoenende verskeidenheid nie ter tafel gekom nie (NHKA 2008:46). Gedurende die 69ste AKV is dit gestel dat die Komitee vir Kerk en Teologie nie uitvoering aan die opdrag van die 68ste AKV gegee het nie. Die opdrag was dat hulle in hulle studie die memoranda wat as basis van die vorige beskrywingspunt oor versoenende verskeidenheid gedien het, vir verdere studie moes gebruik (NHKA 2011a:5).

Die enigste wyse waarop die gedagtes wat in die oorspronklike beskrywingspunt gedien het, tereggekom het, was in die beskrywingspunte aangaande 'n roetekaart vir 'n inklusiewe kerk (2011:92). Laasgenoemde was 'n versoek tot die Hervormde Kerk om homoseksuele persone onvoorwaardelik in die kerk in te sluit. Soos bo aangedui is, is dit nie aanvaar nie. Die Hervormde Kerk was nie bereid om op grond van die konsep van versoenende verskeidenheid homoseksuele persone onvoorwaardelik in die Hervormde Kerk in te sluit nie. Trouens, ten opsigte van homoseksuele en heteroseksuele persone bestaan dieselfde beleid van 'geen gelykstelling' wat gegeld het in die regverdiging van Artikel III. Dit kan gesien word in die kerk se benadering ten opsigte van die pastorale begeleiding van homoseksuele persone. Die Hervormde Kerk het gepoog om 'n aparte stel maatreëls vas te stel vir die opname van homoseksuele persone in die Kerk: 'die Kerk sal daarom basiese beginseluitgangspunte en spesifieke riglyne vir die pastorale versorging van homoseksuele persone opstel en aan alle ampsdraers van die Kerk beskikbaar maak' (NHKA 2008:47).

Die argument sou gevoer kon word dat daar wel ruimte in die Hervormde Kerk is vir besondere of toegespitste pastoraat. In terme van die pastorale versorging van homoseksuele persone spruit hierdie besondere pastoraat egter voort uit die kerk se standpunt dat homoseksualiteit (vanweë sogenaamde afwykende seksuele aktiwiteit) genees kan en moet word

10.Die verskil in amp en bediening word uiteengesit in Ordereël 2 en 3 van die Kerkorde van die NHKA (1997). Daar is verskillende ampte: 'dienaar van die Woord'; ouderling en diaken (NHKA 1997:5). Daar is ook verskillende bedieninge van die verskillende en diaken (NHKA 1997:5). Daar is ook verskillende bedieninge van die verskillende
ampsdraers: verkondiging, toerusting, versorging, beskerming, regering en leiding van die Kerk (NHKA 1997:33). 
(Dreyer 2004:179). Verder was (en is) dit die Hervormde Kerk se beleid dat homoseksuele persone in die Kerk se geledere verwelkom word (inklusief), maar onder sekere voorwaardes (eksklusief). Hierdie voorwaardes is selibate leefwyse en pastorale begeleiding (NHKA 2008:46-47). Dit beteken dat homoseksuele persone gedeeltelike lidmaatskap aan die Hervormde Kerk geniet, op grond van die gedeelte van die homoseksuele georiënteerde persoon wat vir die Kerk aanvaarbaar is: die persoon. Solank die seksuele daad nie plaasvind nie, is hierdie mense geregtig op die voorregte van volwaardige lidmaatskap van die Kerk, wat deelname aan die sakramente en toelating tot die ampte van die Kerk insluit (kyk die beskrywingspunt van die 68ste AKV, punt 6, NHKA 2008:47). Die 66ste AKV van 2001 (NHKA 2001) het ' $n$ beskrywingspunt goedgekeur dat 'n Studiekommissie benoem word om homoseksualiteit as verskynsel te ondersoek om sodoende die 67ste AKV van September 2004 daaroor in te lig en te adviseer. Die 67ste AKV het van die studie kennis geneem en die bespreking aangaande die uitslag van die studie en nog bykomende studie, na die 68ste AKV in 2007 verwys vir bespreking. Tydens die 68ste AKV is bepaalde beskrywingspunte aan die vergadering voorgelê vir oorweging. Die 68ste AKV het nie die beskrywingspunt van die Studiekomitee aangaande Homoseksualiteit aanvaar nie. Uittreksels uit die beskrywingspunt lees:

Die norm van die Skrif is dat alle gelowiges uit die evangelieboodskap leef. In die Protestantse kerk is die vertrekpunt dat redding berus op geloof alleen. Niks vanuit die menslike natuur kan hierdie versoening bewerkstellig nie. God se Gees maak dit vir alle gelowiges moontlik om hulle hele lewe (ook die liggaam) in God se diens te stel.

en;

Die kerk glo dat alle gedooptes, alle gelowiges, lede van die liggaam van Christus is. Die eenheid van die kerk as liggaam van Christus is ' $n$ evangeliese eis. Derhalwe is mense wat tot seksuele minderheidsgroepe (of tot watter minderheidsgroepe ook al) behoort, soos alle ander lidmate, welkom in die Christelike geloofsgemeenskap.

(NHKA 2008:45-46)

Die NHKA erken en bely dus die katolisiteit (algemeenheid) van die kerk, maar laat nie die moontlikheid oop dat verskillende minderheidsgroepe (ook seksuele minderheidsgroepe) onder die koepel van versoenende verskeidenheid in die Kerk 'n tuiste vind nie (Van Wyk \& Buitendag 2010). Van Aarde (2006) stel dit soos volg:

Die geloofwaardigheid van die kerk se strewe om ekumenies te wees, is in gedrang wanneer die kerk 'n groot saak wil maak van uitreik na ander toe, maar nie in staat is om bereid te wees om diegene wat buite is, onvoorwaardelik te sien as potensieel saam met jou in die kerk nie - wat die saam aansit aan die nagmaalstafel insluit ... dit vra om die Ander - insluitende die straatkind, die prostituut, die anders-biologies geskape en anders-seksueel georiënteerde, die anders-volkige, die anderskleurige, die anders-godsdienstige nie as onaanvaarbaar vir inkom in die kerk te beskou nie, omdat hulle nie is soos jy is of is soos jy wil hê hulle moet wees nie.

(Van Aarde 2006:107)

Dus is daar in die Hervormde Kerk se verstaan en hantering van homoseksuele persone ook 'n fragmentasie te sien, wat berus op 'n spanning tussen eenheid en eendersheid, oftewel eenheid en verskeidenheid.

Die grondliggende rede vir die kerk se probleem met hierdie spanning kan gevind word in 'n bepaalde eskatologiese spanning: dat die eenheid van die kerk slegs sal realiseer in die eskatologiese, die hiernamaals, in die onsigbare (Du Preez 1959:107; vgl. Van Eck 1995:835). Volgens Du Preez is die sigbare eenheid van die kerk op aarde 'n ideaal, maar 'n ideaal wat nooit in die sigbare bereik kan word nie. Hierdie stelling van hom bou voort en is inderdaad gegrond op die onderskeid tussen die sigbare kerk en die onsigbare kerk.

Volgens McGrath (2001:496) lê agter Calvyn se sigbare kerk of onsigbare kerk diskoers die onderskeid tussen die waarneembare kerk en die ideale kerk. Dit gaan van die veronderstelling uit dat die teenswoordige onenigheid van die kerk op die laaste dag opgehef sal word. Die teenswoordige situasie is volgens hierdie benadering slegs tydelik en sal opgelos word op die moment van eskatologiese vervulling (kyk Jonker 1994:74).

Calvyn beklemtoon die roeping van die kerk om die kerk se sigbare eenheid te bewaar. Hy formuleer dit onder meer in sy Institusie IV 3.2: ' . . . dat de dienst der mensen, van welke God gebruikt maakt bij het besturen der kerk de voornaamste zenuw is, waardoor gelovigen in een lichaam verbonden zijn'. Die sigbare kerk is die gemeenskap van gelowiges op aarde. Die onsigbare kerk is die gemeenskap van die heiliges en die gemeenskap van diegene wat uitverkies is. Hierdie onderskeid is egter vir Calvyn 'n eskatologiese onderskeid. Ook Walter Kasper, 'n ekumeniese teoloog, meen dat volledige gemeenskap tussen gelowiges in die voltooide sin slegs 'n eskatologiese hoop kan wees (Kasper 2004:71). Op aarde sal die kerk altyd 'n kerk wees wat worstel met spanning, skeuring en afvalligheid. Hy meen daar moet egter onderskei word tussen spanning wat 'n teken van die lewe is en teenstellings wat gemeenskaplike lewe vernietig. In dié sin het Calvyn die sigbare kerk en die onsigbare kerk van toepassing gemaak op die verstaan van die kerk as corpus permixtum, waar waaragtige geloof en gebrokenheid (sonde) in elke kerklid teenwoordig is (Van Selms in Geyser et al. 1960:36). Die sigbare kerk en die onsigbare kerk moet soos 'kerk' en 'koninkryk' van mekaar onderskei word, maar nie van mekaar geskei word nie. Word dit van mekaar geskei, word die sigbare kerk verteenwoordigend van die huidige gebroke werklikheid en die onsigbare kerk verteenwoordigend van die oplos van hierdie gebrokenheid en 'n geheel en al ander werklikheid. In hierdie sin kan die sigbare kerk nie as die negatiewe menslike teenpool van die onsigbare koninkryk beskou word nie (Barth 1972:46; vgl. Van Aarde 1987:329).

Van Aarde (1995:346) meen egter dat, hoewel die kerk nie die negatiewe teenpool van die koninkryk is nie, die kerk ook nie identies aan die koninkryk is nie. Hy haal Wolfgang Trilling (1978) aan wat dieselfde opinie het: 
Die Basileia wird niemals, auch nicht in einer fernen Zukunft, mit der Kirche identisch ... sie bleibt in Gottes Souveränität und in seiner Macht der Freiheit - auch gegenüber der Kirche oder den Kirchen. Und dennoch ist sie gegenwärtig, unser Zeit present.

(Trilling 1978:71)

Die begrippe 'koninkryk' en 'kerk' in hierdie sin benodig egter verheldering. Die Jesus-saak (kyk Van Eck 2009) het te doen met die realisering van die koninkryk van God. Hahn (1986:192) meen dat Jesus nie verwag het dat sy onderrig oor die koninkryk van God eers in die toekoms sal realiseer nie, maar dat dit reeds in en deur sy lewe, dood en lewe gerealiseer sal word. Hy meen verder dat die skeiding tussen die teenswoordige aardse bedeling (wat in terme van die napase Jesus-beweging 'kerk' genoem is) en die toekomstige koninkryk van God beskou word as die produk van bepaalde apokaliptiese strominge in die Jodedom wat die Christene ingesluit het. Van Aarde (1996) beklemtoon dat die kerk volledig menslik is en gebonde is aan mense se bestaan in die aardse bedeling - maar dat die koninkryk die kerk te bowe gaan en oorstyg - in Christus. Laasgenoemde beskou Van Aarde as die grondslag van 'n inklusiewe ekklesiologie (Van Aarde 1996:314). Dus, indien die sigbare kerk teenoor die onsigbare koninkryk wat in die toekoms gerealiseer word, gestel word, word die dringendheid van die appèl tot eenheid (Van Wyk \& Buitendag 2008, 2010) gerelativeer.

\section{Die padversperring op die kerk se reis na inklusiwiteit}

Etnisiteit, seksualiteitsvoorkeure en 'n anti-ekumeniese gesindheid ineengevleg met politieke motiewe, vorm die kontoere van 'n antropologie wat 'n onderskeid maak tussen die sondige mens (sigbare kerk) en die verloste mens (die onsigbare, eskatologiese kerk). Dit dui op 'n fragmentasie in die ekklesiologie van die NHKA. Hierdie fragmentasie in die Kerk word deur 'n spesifieke mensbeskouing geregverdig. Die menslikheid van die kerk is dus die vraag op die tafel. Die Hervormde Kerk se mensbeskouing skyn 'n padversperring op die Kerk se reis na inklusiwiteit te wees. In die debatte rakende sigbaar-onsigbaar/eenheid-eendersheid/ nou-eendag is veronderstel dat die raakvlak tussen God en mens nie 'n saak van die geloof is nie, maar wel een van die natuur.

Volgens Van Wyk (1999:270) is 'n antropologiese onderbou een van die aspekte van die Hervormde Kerk se ekklesiologiese tradisie. Die ekklesiologie van die Hervormde Kerk is deur 'n bepaalde vryheidsbegrip beïnvloed en dit het ontwikkel aan die hand van 'n unieke mensbeskouing:

Menswees is verstaan as Afrikaner-wees. Die identiteit van die Afrikaner is gedefinieer in terme van sy andersheid teenoor Swart mense en Engelse. Andersheid het die implikasie gehad dat menswees nie bedink kon word in terme van die saambestaan van verskillende maar gelykwaardige individue en groep nie, maar slegs kragtens magsverhoudinge teenoor mekaar.

(Van Wyk 1999:271)

Van Aarde meen dat die spanning tussen eenheid en verskeidenheid juis nie opgelos moet word nie - en betoog vir die erkenning van die menslikheid van die kerk (Van Aarde 1995:865 e.v.) - sodat die verskille in menswees nie kerkwees in die wiele ry nie. Jy is juis jy omdat jy nie 'n ander is nie en die ander (autré) definieer jou ook en by die ander bestaan jy juis. Want ' $n$ oormatige beklemtoning van die onsigbare aard van die kerk is juis nie 'n erkenning van die verskeidenheid binne die kerk nie. Dit is 'n aanduiding dat verskille in menswees ontken word en dat inklusiwiteit neerkom op eendersheid. Die norm in die debatte is dat 'n mens Blank, Afrikaans en heteroseksueel moet wees. Almal wat op hierdie manier eenders is - is deel van die kerk. Die verskeidenheid van mense verhinder die Kerk om kerk te wees, want om kerk te wees kom daarop neer om eenders te wees. Ten grondslag van hierdie siening lê ' $n$ gefragmenteerde mensbeskouing. Die kreatiewe dialektiek (wedersydse inwerking en profilering) tussen bogenoemde sake is die konsep van versoenende verskeidenheid en tot dusver het die NHKA min toleransie met die konsep getoon.

In die inleiding van hierdie artikel is verwys na 'n opmerking van 'n lidmaat in die Die Hervormer, die amptelike mondstuk van die NHKA, oor diversiteit. 'n Ander opmerking oor diversiteit in die kerk is: 'as sodanige gebruike voortduur en groter momentum kry, sal die Hervormde Kerk binnekort 'n mosaïek-kerk wees' (NHKA 2011b). Die vraag kan gevra word waarom dit vir die Hervormde Kerk in die lig van die verstaan van versoenende verskeidenheid 'n probleem sal wees om 'n mosaïek-kerk te wees. In die Beeld van April 2009 word 'n mosaïek-kunswerk beskryf deur die uitdrukking: "n gebreekte geheel.' Hierdie metafoor 'gebreekte geheel' gee dialekties uiting aan die tweeledige aard van die kerk: nie ' $n$ grys massa van eenheid nie, nie aparte identiteite nie, maar 'n gebreekte geheel waarin die Hervormde Kerk inderdaad uit sondige en natuurbepaalde mense bestaan: man, vrou, wit, swart - hierdie sake sal nooit verander kan word nie - maar waarin hierdie verskeidenheid getransendeer word.

Daarom benodig die NHKA 'n herstelde en inklusiewe teologiese antropologie as onderbou van die ekklesiologie teenoor die gefragmenteerde ekklesiologie van die kerk se geskiedenis - 'n padversperring op die kerk se reis na inklusiwiteit.

\section{Erkenning Mededingende belange}

Die outeure verklaar dat hulle geen finansiële of persoonlike verbintenis het met enige party wat hulle nadelig kon beïnvloed in die skryf van hierdie artikel.

\section{Literatuurverwysings}

Barth, K., 1960, Die lehre von der Versöhnung, in Die Kirchliche Dogmatik, Vierter Band, Erster Teil, 2 Auflage, EVZ-Verlag, Zürich.

Botha, S.J., 1973, Die volkskerk, HAUM, Pretoria.

Dreyer, J., 1961, 'Die onsigbare kerk en die Rasseprobleem', Die Hervormer Kerkargief, Pretoria.

Dreyer, Y., 2004, 'Homoseksualiteit: Die kerk, die tradisie en die Bybel - homofobie en sarkofobie en die evangelie', HTS Teologiese Studies 60(1\&2), 175-205.

Dreyer, T.F.J., 2011a, “"Wat jy ook op die aarde mag bind, sal in die hemel gebonde wees, en wat jy ook op die aarde mag ontbind, sal in die hemel ontbonde wees" (Matt 16:19)', HTS Teologiese Studies/Theological Studies 67(1), Art. \#914, 4 pages. http://dx.doi.org/10.4102/hts.v67i1.914. 
Dreyer, T.F.J., 2011b, 'Rede gelewer tydens die opening van die Hervormde Teologiese Kollege', ongepubliseerd, Universiteit van Pretoria, Pretoria, 11 Februarie.

Dreyer, W.A., 1995, 'Kerk, volk en owerheid: 'n Hervormde Perspektief', DDproefskrif, Departement Kerkgeskiedenis en Kerkreg, Universiteit van Pretoria.

Dreyer, W.A., 1999, Nederduitsch Hervormde Kerk van Afrika: Die eerste 250 jaar 1652 tot 1902 , Kital, Pretoria.

Dreyer, W.A., 2006, 'Die Nederduitsch Hervormde Kerk van Afrika as volkskerk: Oorsig en herbesinning', HTS Teologiese Studies/Theological Studies 62(4), 1337-1368.

Dreyer, W.A., 2011, 'Journey from isolation', HTS Teologiese Studies/ Theological Studies 67(1), Art. \#869, 9 pages. http://dx.doi.org/10.4102/hts. v67i1.869

Du Preez, A.B., 1959, Eiesoortige ontwikkeling tot die godsdiens: Die hoop van SuidAfrika, HAUM, Pretoria.

Engelbrecht, B.J., 1978a, 'Die onderskeiding tussen onsigbare en sigbare kerk en die betekenis daarvan ten opsigte van die eenheid van die kerk', in NHKA, pp. 11-14, Kerkargief, Pretoria.

Engelbrecht, B.J., 1978b, Teologie in die kerk, red. J.P. Oberholzer, HAUM, Pretoria.

Engelbrecht, S.P., 1929, 'Die groot vraagstuk', Die Hervormer, Januarie 1929 Kerkargief, Pretoria.

Engelbrecht, S.P., 1961, ‘Onaangename plig', Die Hervormer, Januarie 1961 Kerkargief, Pretoria.

Geyser, A.S., 1948, 'Die Kerk in die krisis, I', Die Hervormer, Augsutus 1948, Kerkargief, Pretoria.

Geyser, A.S., Marais, B.J., Du Plessis, H., Keet, B.B. \& Van Selms, A., 1960 Vertraagde aksie: 'n Ekumeniese getuienis uit die Afrikaanssprekende kerk, NG Kerkboekhandel, Pretoria.

Geyser, A.S., 1961, 'Die Skrif bevel 'n sigbare eenheid van die kerk', Die Hervormer, Maart 1961, Kerkargief, Pretoria.

Hahn, F., 1986, Die Petrusverheissung Mt 16, 18f, Eine exegetische Skizze, Band 1 Vandenhoeck, Göttingen.

Jonker, W.D., 1994, Bevrydende waarheid: Die karakter van die gereformeerde belydenis, Hugenote Uitgewers, Wellington.

Kasper, W., 2004, That they may all be one: The call to unity today, Burns \& Oats, London.

Koekemoer, J.H., 1987, Die volkskerkvoorstelling in die Kerkwet van die Nederduitsch Hervormde Kerk van Afrika, HTS Teologiese Studies/Theological Studies 43(1\&2), 13-23.

Koekemoer, J.H., 1990, 'Die na-binne of introverte gerigtheid van "Kerk en Wêreld 2000", HTS Teologiese Studies/Theological Studies 46(4), 708-715.

Komitee van Beswaardes, 2011a, Beswaarskrif, Kerkargief, Pretoria.

Komitee van Beswaardes, 2011b, Kontekstualisering van Beswaarskrif, Kerkargief, Pretoria.

Komitee van Beswaardes, 2011c, Memoranda oor Besluit 54, Kerkargief, Pretoria.

McGrath, A.E., 2001, Christian Theology: An introduction, Blackwell, Oxford.

Nederduitsch Hervormde Kerk van Afrika (NHKA), 1951, Kerkwet en Kerkbepalings van die NHKA, Kerkargief, Pretoria.

NHKA, 1961, Notule van die 53ste Algemene Kerkvergadering, Kerkargief, Pretoria.

NHKA Kommissie van die AKV, 1973, Herderlike Skrywe van die AKV van die NHKA aan die lidmate van die Kerk oor sy opvatting met betrekking tot volkereverhouding in die RSA, Kerkargief, Pretoria.

NHKA, 1978, 'Uitgawe 72', Die Alamanak, Kerkargief, Pretoria.

NHKA Kommissie van die AKV, 1985/6, Kerk en wêreld, Kital, Pretoria.

NHKA Kommissie van die AKV, 1990, Kerk en politiek, Kerkargief, Pretoria.

NHKA Kommissie van die AKV, 1991, Resultate van die TKK, Handelinge van die Afvaardiging van die NG Kerk, die NH Kerk en die Gereformeerde Kerke in SuidAfrika Januarie 1991-Desember 1993, Kerkargief, Pretoria.

NHKA, 1997, Kerkorde van die Nederduitsch Hervormde Kerk van Afrika, Kerkargief, Pretoria.

NHKA Algemene Kerkvergadering, 2001, Agenda/besluitebundel van die 66ste Algemene Kerkvergadering, Bylae $F$, Kerkargief, Pretoria.

NHKA Kommissie van die AKV, 2007, Agenda van die 68ste Algemene Kerkvergadering Addendum tot die Agenda oor die Wysiging van Ordereël 4, Kerkargief, Pretoria.

NHKA Kommissie van die AKV, 2008, Besluitebundel van die 68ste Algemene Kerkvergadering, Kerargief, Pretoria.
NHKA Komissie van die AKV, 2010, Agenda van die 69ste AKV, Kerkargief, Pretoria.

NHKA Kommissie van die AKV, 2011a, Besluitebundel van die 69ste Algemene Kerkvergadering, Kerkargief, Pretoria.

NHKA, 2011b, 'Diversiteit het grense', Die Hervormer, Februarie 2011, Kerkargief, Pretoria.

NHKA Kommissie van die AKV, 2011c, Kerkregtelike nadenke na aanleiding van Beskrywingspunt 54 en die kerklike verloop na die 69ste Algemene Kerkvergadering, Kerkargief, Pretoria.

Oberholzer, J.P., 2009, 'Honderd Jaar Kerk en Teologies Opleiding: 'n Kroniek van die Hervormde Kerk', HTS Toelogiese Studies/Theological Studies 66(3), Supplementum 9 .

Oosthuizen, A.J.G., 1960, 'Ons Kerk', Die Hervormer, Junie 1960, Kerkargief, Pretoria.

Pont, A.D., 1987, 'Die vrye kerk: Enkele opmerkings oor die herkoms en inhoud van die opvatting', HTS Teologiese Studies/Theological Studies 43 (1\&2), 25-43.

Pont, A.D., 1989, 'Die Groot Trek en die Kerk', HTS Teologiese Studies/Theological Studies 45, 655-670.

Storm, J.M.G., 1992, 'Stigters van 'n nuwe land en volk', HTS Teologiese Studies/ Theolgical Studies 48, 923-941.

Stutterheim, J., 1960, 'Die Kerk en Rasse-ideologieë', in A.S. Geyser et al. (reds.), Vertraagde aksie: 'n Ekumeniese getuienis uit die Afrikaanssprekende kerk, pp. 117-124, NG Kerkboekhandel, Pretoria.

Trilling, W., 1978, “IImplizite Ekklesiologie”: Ein Vorschlag zum Thema "Jesus und idie Kirche"', in Die Botschaft Jesu: Exegetische Orientierung, pp. 57-72, Herder, Freiburg.

Van Aarde, A.G., 1987, 'Gedagtes oor die begin van die kerk - 'n geskiedenis van versoenende verskeidenheid', HTS Teologiese Studies/Theological Studies 43(3), 325-351.

Van Aarde, A.G., 1989, "n Nuwe-Tesamentiese begronding van die eenheid van die kerk en die eis om kerkeenheid vandag', HTS Teologiese Studies/Theological Studies 45(2), 461-475.

Van Aarde, A.G., 1995, 'Die menslikheid van en die verskeidenheid in die kerk', HTS Teologiese Studies/Theological Studies 51(3), 865-875.

Van Aarde, A.G. \& Botma, A., 1996, 'Die formule en Christo as basis van die Pauliniese ekklesiologie', HTS Teologiese Studies/Theological Studies 52(2\&3), 285-317.

Van Aarde, A.G., 2006, 'Hoe om in te kom en hoe om binne te bly - die "groot sendingopdrag" aan die kerk vandag volgens Matt 28:16-20', HTS Teologiese Studies/TheologicalStudies 62(1), 103-122.

Van den Berg, C.L., 1960, Onvertraagde Voortgang, Kerkargief, Pretoria.

Van der Westhuizen, H.G., 1981, Vokskerk en Sending, HAUM, Pretoria.

Van der Westhuizen, H.G., 1989, Blankheid en Waarheid, Kital, Pretoria.

Van Zyl, F.J., 1978, 'Is Kerkvereninging vandag of in die toekoms 'n doelwit?', in NHKA, pp. 23-26, Kerkargiewe, Pretoria.

Van Eck, E., 1995, 'JHJA Greyvenstein en AS Geyser se teologiese denke oor die volkskerkgedagte', HTS Teologiese Studies/Theological Studies 51 (3), 825-850.

Van Eck, E., 2009, 'Inklusiwiteit as Evangelie', HTS Teologiese Studies/Theological Studies 65(1) \#304, 10 pages. http://dx.doi.org/10.4102/hts.v65i1.304

Van Selms, A., 1960, 'Die Gemeenskap van die Heiliges en die Kleurvraagstuk', in A.S. Geyser et al., Vertraagde aksie: 'n Ekumeniese getuienis uit die Afrikaanssprekende kerk, 36-47, NG Kerkboekhandel, Pretoria.

Van Wyk, D.J.C., 1978, Stemme uit die verlede I, HAUM, Pretoria.

Van Wyk, D.J.C. jnr, 1999a, 20ste eeu Hervormde Teologie, Sentik, Pretoria.

Van Wyk, I.W.C., 1999b, 'Wat glo ons van die kerk?', in D.J.C. van Wyk (red.), 20ste Eeu Hervormde Teologie, pp. 270-285, Sentik, Pretoria.

Van Wyk, T. \& Buitendag, J., 2008, 'Die dimensies van eenheid en katolisiteit in die Nederduitsch Hervormde Kerk sedert Ottawa 1982', HTS Teologiese Studies/ Theological Studies 64(3), 1447-1473.

Van Wyk, T. \& Buitendag, J., 2010, 'Die eenheid van die kerk in gedrang', HTS Teologiese Studies/Theological Studies 66(1), \#908, 9 pages. $\mathrm{http}: / / \mathrm{dx}$.doi. org/10.4102/hts.v66i1.908

Van Zyl, F.J., 1978, 'Vereniging of Samewerking', in NHKA, pp. 23-26, Kerkargief, Pretoria.

WARC General Council 1982, Racism and South-Africa, A composite statement from section II - 'The Power of Grace and the Graceless Powers,' The Policy Reference Committee, and the Special Committee on Reformed Witness Today, viewed n.d. from http://warc.ch/where/21gc/study

Wolmarans, H.P., 1953, 'Die Christelike plig van die Blankes teenoor die Nie-Blankes in Suid- Afrika', Die Almanak, 1953, Kerkargief, Pretoria. 